\title{
Reformation and the Secular Age
}

\author{
Charles Taylor, McGill University
}

\begin{abstract}
The following is a transcript of a lecture delivered by Charles Taylor during the colloquium " 500 years of Reformation and the World Religions" at McGill University's School of Religious Studies on October 30, 2017. The central concepts and ideas discussed by Dr. Taylor in this lecture were originally proposed in his critically acclaimed book, A Secular Age (2007). ${ }^{1}$ Footnotes have been added to provide additional clarity and context.
\end{abstract}

Key Words: A Secular Age; reformation; secularity; pluralism.

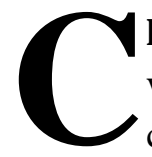

harles Taylor: Thank you very much and thanks for this opportunity to discuss a whole set of issues with a very interesting group of people from different points of view. Now, I've thought maybe we could try to cut through the immense number of things we could say about the relationship between the reformation and the secular age by stipulating a couple of itineraries. The number one being, how to characterize the secular age in the West?

One fast way of doing it is to use a concept that I use in my book called the "immanent frame,"2 and the claim would be that in the modern world, we in the West - and in some respect international society at its apex - see ourselves as living in an immanent frame. By that I mean we have a shared "imaginary" of the world we live in, which goes along with our conscientiousness of taking very different stances towards that world. ${ }^{3}$ An analogy would be how people living in a democracy have some shared sense of how a democracy works what the norms are, what is supposed to give you success or failure in getting elected, etc. - while disagreeing strongly in who should be elected, what policy should be enacted, and so on. In a similar way, I would like to argue that what I am calling the immanent frame is our shared context or framework, above which we nevertheless hold very powerfully different stances; whereas some hold that's all there is, others hold that there's something more to be said - there's some deeper or transcendent reality to deal with.

How to characterize this immanent frame? I think we can see it in the following set of impersonal orders: ${ }^{4}$ the first being that what used to be thought of as the cosmos we now think of as the Universe. ${ }^{5}$ The Universe is ruled by factual, natural law in the post-Galilean-Newtonian sense, and we all accept that we live in that kind

1. Transcribed, edited and annotated by Jennifer Guyver with the permission of Charles Taylor.

2. See Charles Taylor, A Secular Age (Cambridge, MA: Belknap Press, 2007), 542. Taylor introduces the "immanent frame" to describe the dominant social and moral framework extant in the West today. For more on Taylor's concept of "frameworks" see Sources of the Self (Cambridge, MA.: Harvard University Press, 1989), 19-32.

3. The "social imaginary" is a concept that Taylor introduces in Modern Social Imaginaries (Durham: Duke University Press, 2004), 23. It refers to "the ways people imagine their social existence, how they fit together with others, how things go on between them and their fellows, the expectations that are normally met, and the deeper normative notions and images that underlie these expectations" (Modern Social Imaginaries, 2).

4. Taylor uses the Weberian term "impersonal order" to describe a way of thinking about the natural world or human life as governed by a set of dispassionate, mechanistic, or objective rules or laws. While earlier ideas of an impersonal order can be found in Patristic theology, Taylor credits the rise of impersonal orders to the popularization of Providential Deism among the elite in the eighteenth century. See A Secular Age, 270-295.

5. Taylor explains that he uses of the term "cosmos" because it speaks to "our forebears' idea of the totality of existence because it contains the sense of ordered whole. It is not that our universe isn't in its own way ordered, but in the cosmos the order of things was a humanly meaningful one" (A Secular Age, 60). 
of physical universe. Secondly, as against our ancestors who thought of the cosmos as very closely related to the social order - such that the social order was embedded in the cosmos with different levels of being corresponding to different levels of society ${ }^{6}$ - we now see our societies as made up in certain moments: such as, the French Revolution, or Canadian Confederation in 1867, or the signing of the declaration of Independence in Philadelphia in 1776. In other words, the last time there was a major constitutional change we can name who and by what means, and so on. We don't see our societies as living since time-immemorial. There is this idea of society as a set of structures and rules that are set up by people. ${ }^{7}$ Similarly, we very often see that the common version of our ethical views are very much rule governed and thought to be spun out from certain basic principles - like Kantian principles.

In all these ways, we see ourselves as sharing the world - which is very much in the immanent frame - but we disagree very profoundly on whether that's all there is. People who share this frame vary all the way from Richard Dawkins - who thinks it's obvious that everything, including human society, is to be explained in terms of natural science, and therefore nothing further needs to be said, or ought to be said, or even entertained ${ }^{8}$ - to the people in this room, who see the issue of how to live one's life in virtue of being in relation to something beyond the immanent frame. ${ }^{9}$ So that's the secular age in a nutshell.

To ask the question of the relation of the reformation to the secular age, I want to first change the question a little bit because I think the reformation while first and foremost is the reform of Luther and Calvin of the sixteenth and seventeenth century, it's also a fact that Latin-Christendom was racked by reform movements before, going right back to Hildebrand in the eleventh century. ${ }^{10}$ Also, after the Reformation there were such things like the Catholic Reformation and Counter-Reformation, and you cannot but be very conscious of this geographically because of where we are - because we owe Quebec society to the Catholic CounterReformation of the seventeenth century. The French people would not have come out here if they had not been pushed and shoved and mobilized to come across the Atlantic. So this society, in all sorts of ways that you can still see today, is a creation of that mode of Reformation.

6. For a more detailed discussion of how earlier societies understood themselves as part of a cosmic order, see A Secular Age, $149-152$.

7. According to Taylor, one of the changes that precedes the development of the immanent frame is a shift in our perception of time. Whereas pre-modern people recognized a distinction between ordinary - i.e., secular - time and eternal or sacred time, and organized their calendars around moments where these two forms of time would intersect, most people now live exclusively within ordinary time. According to Taylor, this shift in time consciousness contributes to the emergence of "horizontal, directaccess" societies, which are founded by people through a series of historical events. See A Secular Age, 56-59; 197; 207-211; 711-720.

8. See Richard Dawkins, The God Delusion (Boston: Houghton Mifflin Company, 2006). Richard Dawkins is well-known for promoting the belief that science and religion are incompatible, and he presents a strong example of some of the principle tenants of what Taylor calls "exclusive humanism” (A Secular Age, 567; n.835).

9. This lecture was delivered at The School of Religious Studies at McGill University to a public audience largely made up of religious studies scholars and students, theologians, members of the clergy, and religious practitioners.

10. Taylor widens the scope of what is considered "the Reformation" to include earlier movements to reform the Church, as well as later reform movements in Latin Christianity. He argues that, despite their ideological differences, these reforms all share four common features: (1) "they are activist; they seek effective measures to re-order society; they are highly interventionist" (2) they aim to impose uniformity on all members of society and eliminate abnormalities or exceptions; (3) they attempt to reduce differences within society by encouraging conformity with the standards of the elites; and (4) "they are 'rationalizing' in Weber's double sense: that is, they not only involve an increased use of instrumental reason, [...] but they also try to order society by a coherent set of rules.” See A Secular Age, 86. 
So, that being a quick, dirty definition of the secular age and perhaps too quick an indication of what successive reform movements are, what's the relation of one to the other? What is the contribution of reform to this secular age? Here, I confess that the different strands are so interwoven that it's very, very hard to draw a clear line. But I want to take up four themes where you can see a very powerful influence - but not a total determination - of the development towards the secular age from the side of reform.

A big way of indicating the first theme very vaguely is with Weber's term "disenchantment," which he didn't use all that precisely himself because it varies in his usage - and therefore in a certain sense in mine ${ }^{11}$ - all the way from the expulsion of magic in the world to other big changes like, for instance, the change which brings us the seventeenth century natural science revolution where you have the notion of matter as totally uninterpenetrated from the spirit. Weber moves between three levels of disenchantment from the all embracing level of disenchantment as the decline of religion altogether to the narrower one of disenchantment as the expulsion of (what turns out to be called afterwards) magic. Let's look at the narrower one first.

So instead of believing in things like magic potions or rituals such as "beating the bounds" of the parish to keep the demons at bay, or using relics to cure whatever needed to be cured, concepts that are very hard to understand today - take something like the vial of the blood mixed with water of the martyr Saint Thomas Becket and carried from Canterbury: you see, the difference between this kind of substance and what we think of medicinal chemical substances today is that obviously the latter is explained very clearly in terms of natural science causation and is therefore very specific; whereas the vial of the blood of Saint Thomas will do more, only its moral direction is fixed. Your disease to be cured is your problem that you're spiritually deficient and it will help with that - you get this huge move from a world in which such substances make sense to people and are thought to exist, to the world of the immanent frame in which they are more or less marginalized by the very definition of what-causes-what in physical terms. So, there is a little bit of a problem because there's something a bit tautological in this definition. What we in the West came to call magic was identified by what was expelled from our worldview, so in a certain sense there's not something quite independent of magic. Therefore when you try to apply this word to other societies various kinds of difficulties will arise. But it will sort of do for our purposes and the advantage of this is in Weber's word Entzauberung (de-magic-ation or disenchantment), it has the word "magic" at the center of it. So that is one of the big lines of development.

Now, we were propelled along this line of development by a very important feature of reform acting on both sides of the confessional divide: namely the denunciation of certain practices as idolatrous or as somehow attaching God's power to things that are well below it. So you have a very powerful drive, let's call it an antiidolatry drive, in all religions descending from Abraham. We see it in Islam in spades, we see it in the Wahhabimovement of Islam pushing ever and ever farther and delegitimizing more and more practices and sites. And this was definitely part of the thrust of the Reformation, but you see it exists also on the Catholic side, because you get the kinds of reform carried through in seventeenth century France, that very much involved - not as spectacularly, not on the same scale - invalidating certain popular practices, saying that they weren't really Christian and had to be somehow set aside. For instance, you get French bishops later attacking things like Santa Clause because it's obviously a pagan intrusion. So on both sides of the confessional divide, this is part of the thrust of reform and it obviously has some very powerful effect in bringing about a change in consciousness, which is so big and massive that we trouble capturing it.

11. For a fuller discussion on Taylor's use of disenchantment see Michiel Meijer "Fellow travellers on different paths: a conversation with Charles Taylor," Philosophy and Social Criticism (August 2019): 1-18, as well as Taylor's essay "Disenchantment-Reenchantment" in Dilemmas and Connections (Cambridge, MA: Belknap Press, 2011), $285-302$. 
The change in consciousness is the sorting out totally of spirit and matter such that the two can be thought of as utterly different. It's the end of the line of something like Cartesianism because they become separate substances. There is the substantial union that Descartes talks about, which, of course, is totally mysterious because he set it in such a way that you can't make very good sense of it, but it's clear that these are two different substances. Now I would like to argue that in the ancient world things were never seen in this light. Even what people think of as forerunners of modern natural science, like Democritus and the Epicureans talking about atoms in the void and so-on, we have to recognize that for the Epicureans the gods as well as the other things in nature were also part of existence, there wasn't a clear difference between, what we would now call, the spiritual and the material. Of course, if you turn to Plato or Aristotle, you get the understanding that the material things we see around us are inhabited by a force - the form, the idea - and they are all formed by that. You cannot have, for Aristotle, anything that actually existed that is not both matter and form, anything that isn't informed matter. It is this kind of inseparable connection which you see totally broken by Descartes for all the analogies perhaps between the Cartesian soul and the Platonic soul, this is clearly a big step away. And it's a step towards some basic features of the immanent frame. So we could possibly argue that one of the great influences or one of the great causative powers of reform has been to help push us towards this massive separating out of spirit and matter so that we can think of the stuff around us as just, you know, dead air, not penetrated by spirit, in a way that our Greek intellectual ancestors and our medieval intellectual ancestors couldn't conceive. ${ }^{12}$

So that's one aspect of it, but surely this whole story of this separating out of spirit and matter has other streams, other segments, to it. ${ }^{13}$ You can see already during the renaissance with Erasmus, you get a conception of spirit that is already beginning to detach itself and if we now look at another feature of Reformed theology we can now see emerging in the doctrine of the sacraments being altered. Now here, it's not tidy because Luther, as everybody knows, retained a very powerful sense of the real presence - Zwingli is the one, if you want to point fingers, who really made the rupture - but you can see arguments in Calvinism (not so much in Calvin himself) emerging very early on that Christ is up there in heaven and can't be here, can't be part of the sacrament in front of us. So perhaps we have a muddy area in which this other very powerful contributing stream to our modern sorting out of spirit and matter is partly supported by some Reformers, but obviously can be explained by other things moving in our culture. So that's why I say you can see certain features of Reformations in this particular stream that I'm talking about now which contribute, but they're obviously not the whole story. ${ }^{14}$ It's not like it would have been a completely happy, platonic world if Luther hadn't been.

Now, let's look at the second narrative thread that starts off with another feature of all reforms, which is that they want to bring it about that everyone lives up to the full demands of the Gospel. There are periods in church life, in all the different Christian churches that have existed in different civilizations, where (an expression I use in the book that comes from the language of the European Union: "Europe at different speeds") some

12. The change that Taylor describes is more than a theoretical distinction, it is "a sorting out in experience, by which it became possible to relate to certain realities as purely 'natural,' and disintricate them from the transcendent; whereby it eventually became possible to see the immediate surroundings of our lives as existing on this 'natural' plane, however much we might believe that they indicated something beyond" (A Secular Age, 143). It is this form of disenchantment - separation of spirit from matter - that prepares the grounds for the Reformation and Counter-Reformations.

13. See A Secular Age, 130-136. Taylor argues that the "sorting out" of spirit from matter pushed forward by Descartes has a significant effect our understanding of human emotions and social behaviour. It leads towards seeing our passions and desires as stemming from within, and thus as capable of individual control. This ultimately gives rise to what Taylor calls, "the disciplinary society."

14. See A Secular Age, 73-75. Taylor notes that other theological and philosophical positions that inspired the Protestant Reformers, such as the notion of God's "unfettered sovereignty," also contributed to the spread of disenchantment and prepared the way for the Reformation. 
people are more closely linked-in than other people are. Where it's kind of normal to see a Church as containing a lot of lay people - who are doing their duty but aren't really devout in the rest of their lives - all the way through to very saintly, very dedicated monks and nuns, and so on. The idea is that there is a kind of complementarity operating here that became normal. And you see that in all the great post-Axial religions. ${ }^{15}$ When you think of Buddhism in Thailand, you have lay people who are earning merit by feeding monks, who are meant to be living a more dedicated life, and they form a kind of complementarity in a way of life, and it's not abnormal that you have these differences of speed. And I think it's arguable that one of the great driving forces of the Reformation that started off 500 years ago by Luther and Calvin was that we aren't going to allow this idea of supererogation. Luther was very clear about this; that it's not that ordinary, married Christians are living a kind of lower version of the life lived by higher persons and a higher version lived by monks. To the contrary, there is a tremendous homogenization in a certain sense of what the Christian life is that involves side-lining some of these special vocations that are thought not to be superiorly lived but to be deviations. And the attempt, at the same time, to bring everybody up and to clean up the act of various people who are living a more marginal, less tight relationship with the Church. Then again, if you look at my patron saint, Saint Charles Borromeo of Mila in the later sixteenth century Milan, you find something very similar in all this business of dancing in churches and various festivals and so-on - we have got to get rid of all this stuff, it is total disorder, and tighten up the reins!

Now I think that this kind of thing happens in phases. The first phase and then people get more tolerant of deviation, and there can be later bouts of reform in which we have renewal or, what gets called in the United States, "revival." Now, what are the long-term consequences of this recurrent drive to bring everyone up to full speed or full practice? Well, I think it has led to a society or civilization in which - to speak Foucault language - a number of very strong disciplines get introduced and inculcated in people. And here again, we're beginning to get fuzzy causal edges because the construction of the modern state, and we see it happen in the seventeenth century, requires the creation of discipline and organized bureaucracies and the development of the modern economy, it has famously been argued, requires people with certain kinds of discipline and dedication accumulation; as against earlier modes of capitalism where you live on money, trading in Florence in order to become a prince, to live the life that really ought to be lived, becoming a patron of the arts, etc., etc. You get the development of relentless accumulation going on.

Now all those forms of discipline in life, which are... we could argue endlessly to what extent there is a religious motivation for them, to what extent are they motivated by their obvious success in certain kind of worldly ways. On a governmental level, you can make a state compete above its weight, to use a boxing term, in consolatory wars between powers. I'm thinking of Prussia which made itself into one of the great powers of the eighteenth century through tremendous discipline through organization of the civil service, despite a much smaller population than the great six states and in spite of it not having tremendous wealth. And so you get the payoff of this, and Peter the Great is observing this and wanting to do the same thing in Russia. You get this imitation by states of other states, in order precisely to be able to compete in this very tough realm in the end. Very important thing about Europe: unlike other great civilizations, it never managed to coalesce into

15. In A Secular Age, Taylor loosely draws on Karl Jaspers' Axial Age theory - which proposes that between the eighth and third century BCE a major, global change in consciousness occurred that lead to the emergence of contemporary world religions - to describe how religion has changed overtime. See Karl Jaspers, Vom Ursprung und Ziel der Geschichte (Zürich: Artemis, 1949). Religions that emerged during or after this period are known as Post-Axial religions. See A Secular Age, 152-158. 
a single empire in any kind of long-term way, it's always breaking apart. So you get this tremendous competition between states.

So to what extent can we understand this development of the disciplinary society as something that emerges from the impulse of the faith to bring everyone up, and to what extent does it end up being explained by more laïque or secular reasoning. Obviously, one is tempted to say that the more you're looking at the earlier phases, the more you're impelled by theological reasons and the more the system comes into operation, the more it's impelled by the fact you can't make your way in the world without it. Weber is very good on this in that he shows how in the great Protestant Ethic. ${ }^{16}$ He shows how, as it were, we develop into what he calls the "Iron Cage," where the kinds of disciplines we have imposed become absolutely necessary to survive and don't need their original impetus.

So I've given you, along with the fuzzy story along with the separation of spirit out of the material, another fuzzy story. You cannot deny an important contribution of the theological impetus.

The third and the fourth remarks are even more off the wall than the first and second set of remarks. The third one is... and this is a question mark: (obviously, what follows is the first sentence, which doesn't have a question mark) the first sentence is, obviously there is a great push back culturally against this very clear separation of spirit and matter and one of the most important manifestations and furthering this pushback comes from the Romantic Movement precisely because they don't accept this kind of neat separation. And it may be because I've read too much Hegel in my youth ${ }^{17}$ but I seem to see in the German case the very early development of a very, intellectually worked out position of push back. The generation of the 1790s in Germany, which incidentally mixed both philosophers and poets and others, they talked to each other. In Jena or Berlin they were always in constant discussion. So, you get a very worked out, elaborate theory here about both poetics and philosophy. The whole idea of Geist and Nature. And yet, to what extent is this so much emerging in Protestant media in Germany? Here is where the question mark comes at the end of the paragraph. To what extent is that something that also could be in a more indirect way, at a later phase, attributed to something here in German protestant culture? Now, once again, once the romantic themes become part of the world and it includes recruits from across the world in every conceivable country of confession and nonconfessional allegiance, and it will also recruit people who will become atheists or deviate very much from Christianity, but it's a question mark if you want to look at the long term consequences of the Reformation. Here more the Lutheran rather than Calvin Reformation. ${ }^{18}$

And the fourth line of narrative I want to look at is another feature of the secular age that wasn't contained in my image of the immanent frame: our age in the West is so much an age of spiritual searching in more and more different directions, including ones that didn't exist before or ones imported from different cultures, or different takes on various Christian traditions. ${ }^{19}$ This kind of pluralization (which I think is a very crucial feature of our world in the modern west, and which rejoins other cultures that have always existed in a state of pluralisation) is moving out of what our main political, theological culture was, which was the culture of

16. See Max Weber, The Protestant Ethic and the Spirit of Capitalism, trans. Talcott Parsons (New York: Scribner, 1958). 17. Taylor's first major publication was on G.W.F Hegel. See Charles Taylor, Hegel (New York: Cambridge University Press, 1975).

18. Taylor makes some early observations about the influence of the Reformation on German society during Hegel's life in Hegel, 399-403; 505.

19. For more on the emergence of religious pluralism in the West, see Charles Taylor, A Secular Age, 423-436. 
Christendom; which was whole societies that were organized around the Christian faith or, in the case of confessional societies, certain versions of the Christian faith.

So that their art, their politics, their mores, etc., were all meant to be informed by, in some sense, the Christian commitment. As against that we have a world where now, more and more, what holds the whole society together is unhooked from very strong religious or spiritual commitment, which, on the contrary, are becoming more variant in society.

Does this have to do with the Protestant Reformation? You can make the argument that the pioneer in this kind of pluralization is the United States. Of course, it wasn't the same kind of pluralisation back then when they made the First Amendment. When they insisted on the First Amendment many of the states had established churches, but they weren't the same established churches, and they didn't want the federal state to come in and favour one or the other. So there was nothing ideologically against there being an established religion, but it very likely developed in that direction through later revival movements and great awakenings. And you get this tremendous pluralization - which is not at all the same kind we have today because it was all Protestant Christians, but it was the direction this model has moved in American history and therefore in western history - that is the gradual widening scope. First of Papists from Ireland get included, then more and more people get included, and now, with some really serious push back from Trump and his followers, Muslims are being included. So you could argue that something of the Protestant principle is presiding over this pluralisation that would be a major feature of our contemporary secular world. ${ }^{20}$

So these would be the four that I'm talking about: disenchantment, then the push back of immense pluralisation, and in all four, you can argue, there is a mark of the great Reformers. So let me stop there.

20. See A Secular Age, 440-466 for a fuller account of the connections between the Reformation and modern religious and spiritual pluralism. 


\section{Bibliography}

Dawkins, Richard. The God Delusion. Boston: Houghton Mifflin Company, 2006.

Jaspers, Karl. Vom Ursprung und Ziel der Geschichte. Zürich: Artemis, 1949.

Meijer, Michiel. "Fellow travellers on different paths: a conversation with Charles Taylor." Philosophy and Social Criticism (August 2019): 1-18.

Taylor, Charles. Hegel. New York: Cambridge University Press, 1975.

Sources of the Self. Cambridge, MA: Harvard University Press, 1989.

Modern Social Imaginaries. Durham: Duke University Press, 2004.

A Secular Age. Cambridge, MA: Belknap Press, 2007.

."Disenchantment-Reenchantment." In Dilemmas and Connections, 285-302. Cambridge, MA: Belknap Press, 2011.

Weber, Max. The Protestant Ethic and the Spirit of Capitalism. Translated by Talcott Parsons. New York: Scribner, 1958. 
